\title{
RESEARCHPAPER
}

\section{Effect of serum leptin concentration on cognitive ability of male and female Vanaraja chickens}

\author{
KULDEEP KUMAR PANIGRAHY ${ }^{1}$, KUMARESH BEHERA ${ }^{2}$, SHAILESH KUMAR GUPTA ${ }^{1}$ AND \\ SASMITA PANDA ${ }^{2}$

\begin{abstract}
${ }^{1}$ Division of Livestock Production and Management, National Dairy Research Institute, KARNAL (HARYANA) INDIA

${ }^{2}$ Department of Livestock Production and Management, College of Veterinary Science and Animal Husbandry, Orissa University of Agriculture and Technology, BHUBANESWAR (ODISHA) INDIA
\end{abstract} \\ Email : kul.pani42@gmail.com
}

Article Info : Received : 03.07.2016; Revised : 01.09.2016; Accepted : 17.09.2016

In males, the intelligent birds had significantly higher level of serum leptin than the dull birds $(0.62 \pm 0.06 \mathrm{vs} .0 .42 \mathrm{~b} \pm 0.08 \mathrm{ng} / \mathrm{ml})$. Similar trend was also visible in female birds $(1.03 \pm 0.13 \mathrm{vs} .0 .78 \mathrm{~b} \pm 0.12 \mathrm{ng} / \mathrm{ml})$. Leptin acts to facilitate long-term potentiation in the hippocampus, a process important for memory processing, which was evident from the present study. Hence, this may be a reliable indicator of cognition. Females had a higher level of leptin concentration in serum than males, but that did not necessarily reflect their performance in terms of cognitive and conditioning abilities. This might be due to higher adiposity in females than males.

Key words : Serum leptin concentration, Cognitive ability, Vanaraja

How to cite this paper : Panigrahy, Kuldeep Kumar, Behera, Kumaresh, Gupta, Shailesh Kumar and Panda, Sasmita (2016). Effect of serum leptin concentration on cognitive ability of male and female Vanaraja chickens. Asian J. Bio. Sci., 11 (2) : 309-312.DOI : 10.15740/HAS/AJBS/ 11.2/309-312. 